Case report/Kazuistyka

\title{
Aloplasty of an ankylosed knee in a patient with severe haemophilia A
}

\section{Aloplastyka stawu kolanowego z ankylozą u pacjenta z ciężka postacią hemofilii A}

\author{
Jerzy Mirosław Jaworski ${ }^{1, *}$, Adam Zawojski ${ }^{1}$, Joanna Zdziarska ${ }^{2}$, \\ Krzysztof Czernicki ${ }^{3}$, Magdalena Wilk-Frańczuk ${ }^{4}$ \\ ${ }^{1}$ Orthopaedic Ward, Cracow Center of Rehabilitation and Orthopaedics, Cracow, Poland \\ ${ }^{2}$ Hematology Department, University Hospital in Cracow, Poland \\ ${ }^{3}$ Rehabilitation Ward, Cracow Center of Rehabilitation and Orthopaedics, Cracow, Poland \\ ${ }^{4}$ Rehabilitation Clinic, Institute of Physiotherapy, Jagiellonian University - Collegium Medicum, Cracow, Poland
}

\section{A R T I C L E I N F O}

Received: 04.07.2017

Accepted: 20.07.2017

Keywords:

- Knee aloplasty

- Rotating-hinge type prosthesis

- Haemophilia

- Ankylosis

Słowa kluczowe:

- Aloplastyka kolana

- Endoproteza rotacyjno-zawiasowa

- Hemofilia

- Ankyloza

\section{Article history:}

Available online: 29.07 .2017

\section{A B S T R A C T}

The goal of this report is to describe a case of knee arthroplasty in a patient with over a 20 year long history of ankylosis of the left knee joint in the course of severe haemophilia A. Clinical and functional conditions were assessed by means of a Knee Society Score (KSS); pain intensity by Visual Analogue Scale (VAS); and intensity of degeneration of bone forming the joint by means of the Kellgren-Lawrence Scale. ROM of the knee joint before and after the operation was measured. We used hinge prosthesis of S-ROM by De Puy to restore the knee joint. As a result of the operation we got axial alignment of the limb. During two years of clinical follow-up, the patient achieved increasing mobility of the operated knee, full extension, and 80 degrees of active flexion. There were no radiological signs of loosening of the implant. The patients' functional capabilities improved significantly; and pain occurred only occasionally.

(c) 2017 Polskie Towarzystwo Hematologów i Transfuzjologów, Instytut Hematologii i Transfuzjologii. Published by Elsevier Sp. z o.o. All rights reserved.

patients with haemophilia were completed with good functional results.

\section{Material and methods}

the Cracow Centre of Rehabilitation and Orthopaedics starting from June 2010. The perioperative period is managed in close cooperation with the Haematology Department of the University Hospital in Cracow. Thus far, 160 procedures in
M. T., was a 40 year old male with severe haemophilia A without inhibitor and generalized secondary haemophilic

\footnotetext{
* Corresponding author at: Al. Modrzewiowa 22, 30-224 Kraków, Poland. Tel.: +48 124287308; mobile: +48 602434176.

E-mail address: jerzymir@poczta.onet.pl (J.M. Jaworski). http://dx.doi.org/10.1016/j.achaem.2017.07.008 0001-5814/@ 2017 Polskie Towarzystwo Hematologów i Transfuzjologów, Instytut Hematologii i Transfuzjologii. Published by Elsevier Sp. $\mathrm{z}$ o.o. All rights reserved.
} 

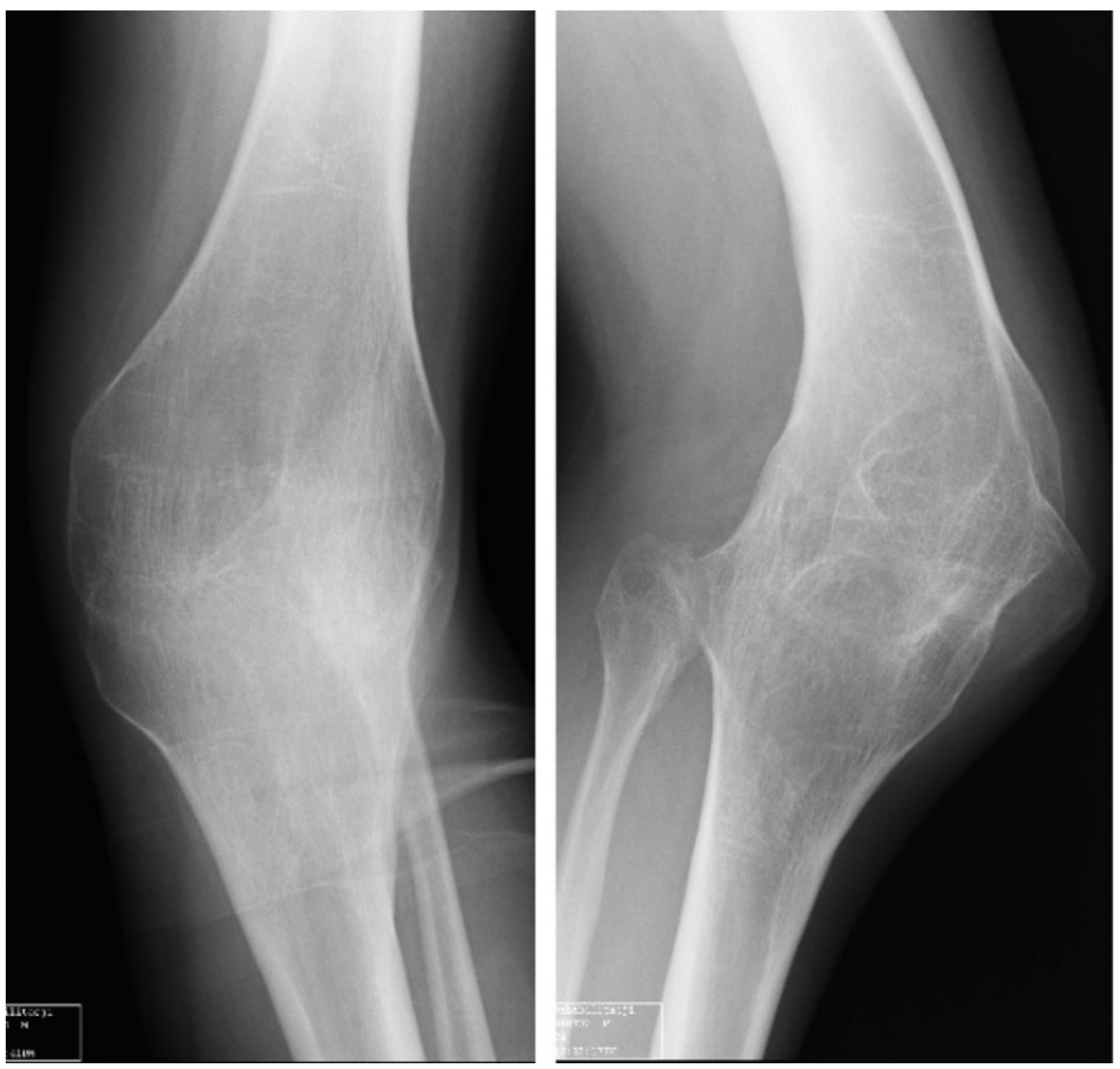

Fig. 1 - Preoprative X-ray of the left knee in a-p and lateral view Ryc. 1 - Zdjęcie Rtg przedoperacyjne lewego stawu kolanowego w projekcji AP i bocznej

arthropathy of multiple joints. He was referred to our Centre for surgical correction of the left lower limb axis. The progressive degenerative process of the left knee, secondary to often intraarticular bleedings, started early in childhood and resulted in ankylosis of the knee joint. In addition, disturbance of the anatomical axis of the limb, making it functionally shorter, led to a significant impediment while walking. Through a compensatory mechanism, the left equinus foot developed. The patient moved using crutches and presented with a pathologic, insufficient pattern of walking. Radiosynovectomies of both knee joints were performed in 10th and 11th year of life.

In 2011, the patient underwent aloplasty of the right knee, and in 2013 aloplasty of the left hip. Clinical follow-up examinations and the patient's subjective assessment of the results of previous operations caused him to try to improve life quality and functional possibilities of the left limb as a whole.

An orthopaedic examination revealed functional shortening of the limb by $4 \mathrm{~cm}$, disturbance of anatomical limb axis, 30 degrees of valgus, and a 40 degree of flexion contracture (Fig. 1), no movement of the left knee joint. Xray examination showed ankylosis - grade 4, of degenerative arthritis according to the Kellgren-Lawrence scale [1].

The patient's stated dream was to correct the long axis of the limb to get back supportive function of the limb at the least. He was informed about the possibility of corrective osteotomy followed by osteo-synthesis with an external stabilizing device. He was also informed about an alternative treatment such as implantation of revision rotationalhinge prosthesis, provided anatomical conditions (muscles, bones) were favourable intraoperatively [2]. All possible problems and complications perioperatively were widely discussed with the patient. He consented to all procedures and actions to be taken on by the operating team.

\section{Method of treatment}

The operation was performed in January 2014 under general anaesthesia, with no tourniquet use. A preoperative dose of $48 \mathrm{IU} / \mathrm{kg}$ of plasma-derived factor VIII concentrate was administered and the post-infusion level was confirmed to be sufficient (118\%). The joint was opened in a typical way, with parapatellar access to ankylosis. Severe arthrofibrosis of patello-femoral joint and ankylosis between the femur and tibia were ascertained. After wide liberation of the soft tissue, both tibial, femoral condyles, and cicatrix of menisci were revealed. The next step of operation was biplanal medially opened wedge-shaped osteotomy. After osteotomy was accomplished we estimated the functional state of the muscles, especially the extensor apparatus, and found it to be quite good, giving chance for a successful prosthesis implantation. Using an intramedullary sight-rod, we cut the 


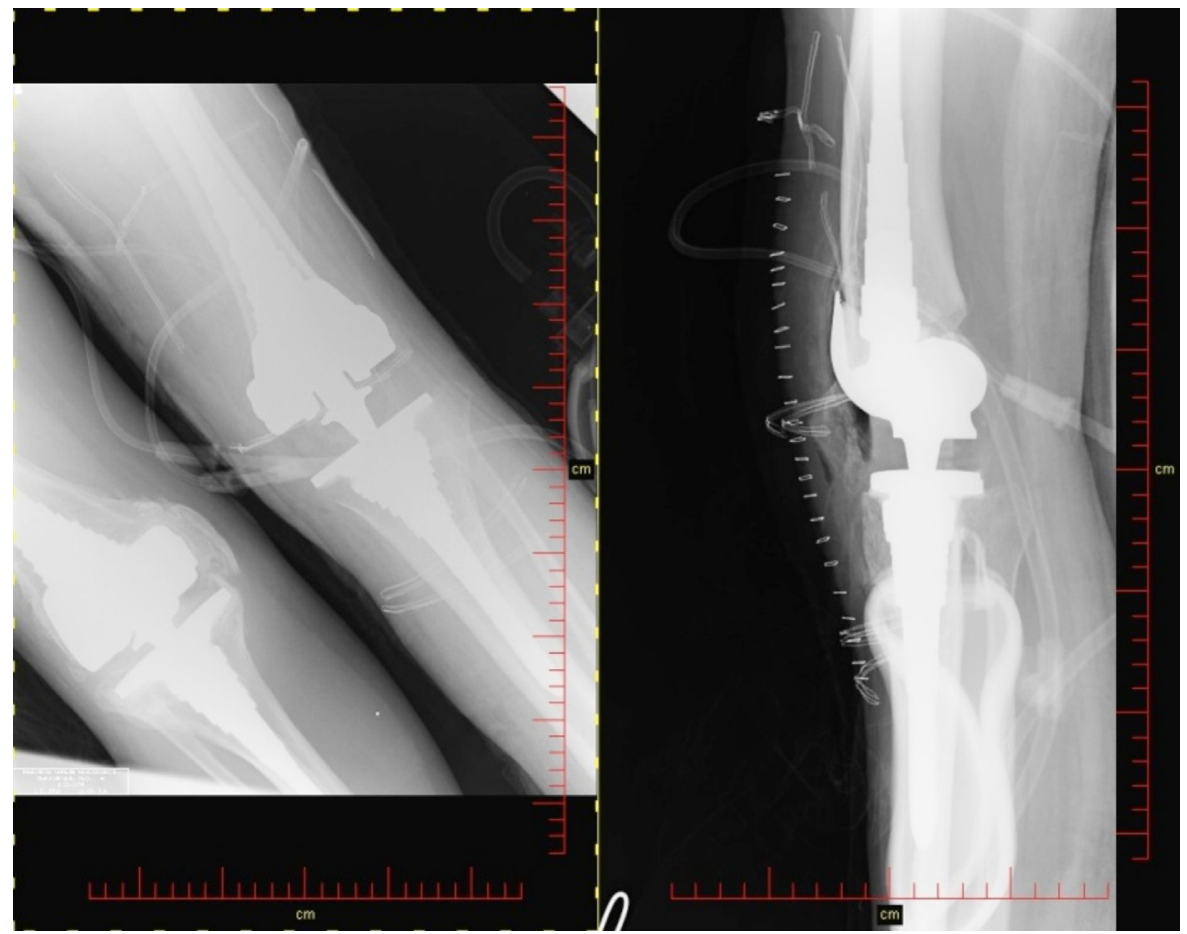

Fig. 2 - Postoprative $x$-ray of the left knee in a-p and lateral view Ryc. 2 - Zdjęcie Rtg poooeracyjne lewego stawu kolanowego w projekcji AP I bocznej

future articular ends of both femur and tibia, and prepared them to imbed both metaphyseal sleeves and the femoral and tibial components of the S-ROM de Puy prosthesis, toughened by intramedullary stems, due to the poor quality of bone (Fig. 2). Prosthesis was fixed by means of bone cement with antibiotic gentamicin. Intraoperatively we got the ROM of full extension and $80^{\circ}$ flexion of the operated knee. The operation lasted two hours. An intraoperative dose of $12 \mathrm{IU} / \mathrm{kg}$ factor VIII concentrate was administered. Postoperatively, the patient lost about $1500 \mathrm{ml}$ of blood during the first two hours; he received $600 \mathrm{ml}$ of his own blood in re-transfusion. In addition, he was infused 4 units of RBC concentrate and 2 units of FFP. Factor VIII concentrate was given every $8 \mathrm{~h}$ in a dose of $24 \mathrm{IU} / \mathrm{kg}$. We used two suction drains, which we maintained for $48 \mathrm{~h}$ after operation. The operated limb was splinted in a plaster splint for $48 \mathrm{~h}$, followed by early rehabilitation using a CPM device (continuous passive motion). No complications occurred in the early postoperative period or during the follow-up period. Factor VIII plasma level was measured daily and the concentrate dose adjusted to maintain the trough level above $80 \%$ in the first week and above $60 \%$ in the second week.

\section{Results}

Initially, the patient walked with crutches. During the first two weeks of the postoperative period he got ROM from -5 degrees of extension to 45 degrees of flexion. Rehabilitation was then continued in the Rehabilitation Ward of our Centre, where he spent 6 weeks. The factor VIII plasma level was maintained above $30-40 \%$ with twice daily concentrate injections. On discharge from the Centre the patient achieved ROM from full extension to 70 degrees of active flexion. Passive flexion with a CPM device reached $80^{\circ}$. During the clinical examination after 2 years follow-up, the patient demonstrated effortless walking, with no more crutches and inconspicuous limping; the patient did not complain about the ailment. ROM revealed 80 degrees of active flexion and full extension, pain occurred occasionally and never exceeded 2 on VAS. According to the KSS functional scale, the patient achieved 90 points, and 86 points on clinical measure. Both functional and clinical results improved in comparison to the pre-operative period, when they were 30 and 66 respectively. X-ray control did not reveal any radiological signs of prosthesis loosening. $\mathrm{He}$ returned to work. In the patient's opinion the final result was excellent, and he reported that if he had to decide again, he would undergo the operation.

\section{Discussion}

Haemophilia is a genetically transmitted, X-linked disease affecting mainly males. Due to deficiency of a coagulation factor, patients suffer from bleedings, usually intraarticular - mostly to the ankles, knees and elbows, but also to muscles, CNS, and parenchymatous organs [3-5]. Numerous bleeds during the course of a lifetime lead to secondary degenerative joint disease, also seen in young adults [6].

The main challenge in the reported case was the fact that the patient suffered no pain. He complained of the problem with moving as a derivate of the deviation of limb 
axis and ankylosed knee. Good clinical results of previously performed aloplasties in this patient encouraged him to try to improve his quality of life by improving the functional condition of the limb and moving possibilities. He expected from the surgeon only the correction of limb axis. Based on previous operative experiences and the results achieved in other patients with haemophilia, we decided to do more: to implant the knee prosthesis.

According to Comanho [7], who described 9 patients with ankylosed knee who underwent TKA, all showed improvement both in pain and ROM. Based on this observation investigators hypothesized that TKA is a treatment of choice in an ankylosed knee. Strauss et al. [8] divided their patients with haemophilia into two groups: group 1: with stiff knee, ROM to $50^{\circ}-23$ knees; and group 2: with no stiffness, ROM more than $50^{\circ}-27$ knees. After TKA was performed, the mean improvement of ROM in group 1 with previously stiff knee was $46^{\circ}$, and in the other group $\leq 9^{\circ}$. Investigators confirmed, that TKA in patients with haemophilia with progressing loss of ROM is an efficient procedure. Cohen et al. [9] demonstrated that in spite of possible complications that can occur after TKA in patients with haemophilia, this procedure in the long-term improves the quality of life.

After reviewing the patient's medical history and current clinical condition, a mobile-hinge prosthesis was recognized as the most suitable one. Felli et al. [10] observed $91.7 \%$ survival of mobile-hinged prostheses during a 13-year follow-up in patients with RA used as primary and revision aloplasty. Petrou et al. [11] describe usage of this kind of prostheses in 80 patients with a mean followup of 13 years, also, with $91 \%$ of good to excellent results. We found one report describing the use of S-ROM De Puy prosthesis in 16 cases of primary and revision aloplasties in patients with large instability of the knee joint [12]. During a 2-year follow-up the authors observed no prosthesis loosening.

Sunnassee et al. [13] describe the use of mega-prosthesis in the treatment of musculoskeletal complications in 5 patients with haemophilia: two of them presented with pseudotumors; two with periprosthetic fracture; and one with mixed contracture ROM of $(-18)$ up to $56^{\circ}$. One patient with a pseudotumor had a limb amputation due to recurrent bleeding; the rest demonstrated diminishing complaints and improved ROM. A case of stiff knee, ROM improved up to $0^{\circ}-$ $110^{\circ}$. They concluded that mega-prosthesis is a good alternative method of treatment of complicated TKA aloplasties.

\section{Conclusion}

Our opinion is that using rotating hinge prosthesis in the reconstruction of an ankylosed knee of haemophiliac patients is the treatment of choice. Prosthesis gives the chance to set the knee in motion, despite years of immobilization and atrophy of musculoskeletal system. One should point out that the success is the result of close collaboration between the haematologist, orthopaedic surgeon, patient and rehabilitants [14], which is the gold standard in our Centre.

\section{Authors' contributions/ Wkład autorów}

J - work concept, data collection and interpretation, critical reviewing, work preparation, collection of literature. AZ work concept, data collection and interpretation, work preparation, collection of literature. JZ - data collection and interpretation, work preparation. KC - data collection and interpretation. MWF - data collection and interpretation.

\section{Conflict of interest/ Konflikt interesu}

None declared.

\section{Financial support/ Finansowanie}

None declared.

\section{Ethics/ Etyka}

The work described in this article has been carried out in accordance with The Code of Ethics of the World Medical Association (Declaration of Helsinki) for experiments involving humans; EU Directive 2010/63/EU for animal experiments; Uniform Requirements for manuscripts submitted to Biomedical journals.

\section{REFERENCES/ PIŚMIEN N I T W O}

[1] Kellgren JH, Lawrence JS. Rheumatoid arthritis in a population sample. Ann Rheum Dis 1956;15(1):1-11.

[2] Rodriguez-Merchan EC. Aspects of current management: orthopaedic surgery in haemophilia. Haemophilia 2012;18:8-16.

[3] Windyga J, Chojnowski K, Klukowska A, Łętowska M, Mital A, Podolak-Dawidziak M, et al. Polskie zalecenia postępowania we wrodzonych skazach na tle niedoborów czynnika krzepnięcia. Część I: Zasady postępowania w hemofilii A i B. Acta Haematol Pol 2008;39(3):537-564.

[4] Riva S, Bullinger M, Amann E, von Mackensen S. Content comparison of haemophilia specific patient-rated outcome measures with the international classification of functioning, disability and health (ICF, ICF-CY). Health Qual Life Outcomes 2010;8:139.

[5] Acharya SS. Exploration of the pathogenesis of haemophilic joint arthropathy: understanding implications for optimal clinical management. Br J Haematol 2011;156:13-23.

[6] Gleb K, Zawojski A, Zdziarska J, Szwarczyk W. Fizjoterapia po zabiegu endoprotezoplastyki stawu skokowego u pacjenta chorego na hemofilię - opis przypadku. Acta Haematol Pol 2015;46:318-325.

[7] Camanho GL. Total arthroplasty in ankylosed knees: a case series. Clinics 2009;64(3):183-187.

[8] Strauss AC, Goldmann G, Schmolders J, Müller MC, Placzek $\mathrm{R}$, Oldenburg J, et al. Impact of preoperative knee stiffness on the postoperative outcome after total knee arthroplasty in patients with haemophilia. Z Orthop Unfall 2015;153 (5):526-532. 
[9] Cohen I, Heim M, Martinowitz U, Chechick A. Orthopaedic outcome of total knee replacement in Haemophilia A. Haemophilia 2000;6(2):104-109.

[10] Felli L, Coviello M, Alessio-Mazzola M, Cutolo M. The EndoModel ${ }^{\circledR}$ rotating hinge for rheumatoid knees: functional results in primary and revision surgery. Orthopade 2016;45 (5):446-451.

[11] Petrou G, Petrou H, Tilkeridis C, Stavrakis T, Kapetsis T, Kremmidas N, et al. Medium-term results with a primary cemented rotating-hinge total knee replacement. A 7- to 15-year follow-up. J Bone Joint Surg Br 2004;86(6): 813-817.
[12] Jones RE, Skedros JG, Chan AJ, Beauchamp DH, Harkins PC. Total knee arthroplasty using the S-ROM mobile-bearing hinge prosthesis. J Arthroplasty 2001;16(3):279-287.

[13] Sunnassee Y, Wan R, Shen Y, Xu J, Southern EP, Zhang W. Preliminary results for the use of knee megaendoprosthesis in the treatment of musculoskeletal complications of haemophilia. Haemophilia 2015;21(2): 258-265.

[14] Wallny TA, Strauss AC, Goldmann G, Oldenburg J, Wirtz DC, Pennekamp PH. Elective total knee arthroplasty in haemophilic patients. Proposal for a clinical pathway. Hamostaseologie 2014;34(1):23-29. 